\title{
ACRL President Kirk focuses on metworking
}

My theme is networking. Of course that conjures up a number of thoughts. For one it suggests the new technology that has become a

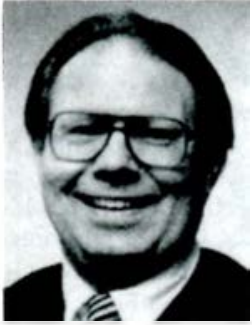

Thomas Kirk larger and larger part of our professional lives. For another it represents a way of professional life. Networking is the sharing of our strengths with others in ways that mutually enhance our ability to achieve individual objectives. In times of financial difficulty networking-electronic, organizational, and persona-offer tremendous opportunities to advance ACRL's and your library's goals. My theme provides a reminder of the priorities of ACRL (See p. 457) and asks you as members to intentionally focus on how you are networking with library colleagues, faculty colleagues, computer center colleagues, other professional associations, and the political process to enhance academic library service to teaching, learning, and research communities.

\section{Networking is the sharing of our strengths with others in ways that mutually enbance our ability to achieve indi- vidual objectives.}

I would like to note several projects that will be (or have been) carried out in this year that are in addition to the strategies identified on page 459.

- ACRL has successfully conducted four preconferences at Al.A's Annual Conference in June. Two of these conferences were jointly sponsored. One with the Coalition for Networked Information (CNI) and another with LITA and LAMA.

- The Bibliographic Instruction Section will cooperate with CNI to compile examples of instructional material for teaching Internet use and pedagogical issues that need to be addressed.

- For next June's annual meeting in Miami the sections and committees of ACRL are cooperating to create and ACRL Conference pro-

\section{I will measure ACRL's success in the next year by bow well all of you have achieved your goals and objectives.}

gram package on a broad range of networking issues to meet the professional development needs of our diverse membership.

I ask you to think about projects and activities in which you are involved that illustrate the power of networking to enhance achievement of the goals of your library or academic libraries generally. I would like to hear about those projects and activities. I will be looking for examples to use throughout my term as president to illustrate the creative talents of academic librarians. Please send me your examples.

You will read more about the particulars of ACRL's activities for next year in ACRL publications over the next months. While I have a theme I do not have a program separate from that of the board, committees, sections, and chapters of ACRL. I will measure ACRL's success in the next year by how well all of you have achieved your goals and objectives.

I want you to share with me any thoughts you might have about ACRL's work. If you have concerns please be in touch. I offer no magic solutions for fixing things. I do offer an ear to listen and a promise to follow up with issues that need exploration. This is a form of networking that we can use within ACRL to make it a more effective professional association. I thank you for your work on behalf of ACRL in the past. I look forward to working with you in the year ahead.-Thomas Kirk, ACRL President, Hutchins Library, Berea, KY 40404; bertgk@ukpr.uky.edu 